\title{
Feminine Voices in Emily Dickinson's Poetry
}

\author{
Kunming Yao \\ School of Foreign Languages, Daqing Normal University, China
}

Keywords: Emily Dickinson; feminism; feminine consciousness.

\begin{abstract}
Emily Dickinson is not really influenced by Feminism movement or by its anthology, but if we study her poems from the perspective of Feminism, the consciousness of Feminism is reflected obviously in her theme of death, life, nature, love and marriage. Under the background of 19th century, her special life experience has reflected her consciousness of feminism, which is a kind of ideology marked with classical feature of women and their understanding. This kind of ideology can be expressed by exploring one's inner heart and creating poems. Feminism is a kind of strategy for Emily Dickinson to understand and experience life in order to realize the independence of her spirit and personality.
\end{abstract}

\section{Definition of feminine}

From the description of the education, family life and lifestyle, of Emily Dickinson getting the environment has influenced her consciousness of Feminism. Feminism in Emily Dickinson's time, states influencing on Dickinson in all aspects. Based on feminine point of view, find her special life experiences has reflected her consciousness of feminism, which is a kind of ideology marked with classical feature of women and their understanding. The excellence of Dickinson's poems from the feminism point of view is obvious.

\section{Dickinson's education influences her feminine point of view}

Emily Dickinson lived in a particular historical revolutionary period. In the political sphere, the United States had get rid of colonial rule, and lived through the American Civil War and post-war development and transformation. Dickinson's grandfather was the founder of Amherst College. Her father was the town's chief lawyer. Traditional, affluent family environment provided Dickinson a good cultural education. After graduated Prism Street primary school, she was admitted to Amherst Middle School, where she studied the Bible, Latin, history, botany, writing, philosophy courses. Six years later, she enrolled in the Mount Holyoke Female College in South Hartley. Her outstanding achievements and amazing imagination soon won the appreciation of her teachers and schoolmates. It was at this period that she underwent a severe religious crisis. There was a thick religious atmosphere in the school, reflecting in student learning and life. Emily Dickinson tried to accept the thoughts of religion, but she learns from these crises that no one else could save her, that she must save herself. She clearly realized that as a woman, she should gain herself independent especially in spiritual.

In the 19th century, religious atmosphere in the New England region of the United States was very strong. There were eight times religious rising movements between 1840 and 1860 in Amherst Town, where Dickinson lived. Calvinism still ruled the town, penetrated into every aspect of people's life. In this town, people go to church Sunday to pray twice. The education Dickinson received was mainly Christian Calvinism and she grew up in a family like that. As a result, Emily Dickinson's childhood was greatly influenced by strict Puritan ideas. Impacts on her thoughts from her devout Puritan father's were especially profound. In Dickinson family, everybody must behave strictly in accordance with the Christian canons. So Emily Dickinson's life is drab and equability. 


\section{Feminine perspective within society in Emily Dickinson's time}

Emily Dickinson's feminine consciousness influences all aspects of her life. She tired to form her own unique system of religious theology, reflecting her belief. Emily pursuits freedom and the equal rights with male. Her love and nature point of view all reflect the influence of feminine on her life, which is mainly expressed by her attitude towards life and pursuit for the free environment of creation.

In her poem "My life had stood — a Loaded Gun", (Dickinson, 1976: 754) Dickinson regarded her own life as a loaded gun, which meant her rebel against traditional women image (Haitao Peng, 2009: 47). Her living space, containing house, courtyard, flowers, grass and trees, had become a spiritual paradise where she could expressed her self-pursuit and affection freely — in a free and comfortable environment, she engaged in her poetry writing which she was longing for. In Emily Dickinson's opinion, only poems could provide her with clearer and more incisive mind.

She desired to become an awakening female poet who could write poetry and cultivated herself in a free world. This was just spiritual force that supported her to withstand various kinds of interference and devoted herself to writing poems in a male-central society by a female thin body. In many poems, Dickinson expressed her desire of the free world:

The grass so little has to do -

A sphere of simple green -

With only butterflies to brood -

And bees to entertain.

(Dickinson, 1976: 333)

Being away from the hubbub brought Dickinson free world instead of loneliness; and self-annihilation brought her the sense of security and free space for creation to extend freely (Johnson, 1955: 187).

Emily Dickinson had an understanding of women's perspective within society, and her poems suggested that the female who were inferior to the male were dependent on the male. What's more, the female had no right in economy, society and politics and were regarded as the citizens in second class, most of their rights being deprived. However, Dickinson was against the dominant status of the male and doubted the traditional mind, which reflected she became aware of the fact that the female owned the secondary status.

According to feminist gender criticism, the female perspective is of little consequence to most in a modern, patriarchal society, and traditionally the roles of women are secondary to those of men. The poem "Success is counted sweetest" (Dickinson, 1976: 67) illustrates this secondary role of women in society by using death as a metaphor to symbolize women's separated social position. It was written in the first person perspective, has Dickinson describing women's experience in society as silent and separate. It is this separateness, illustrated in "Success is counted sweetest", that is perpetuated by men's alienation of women in patriarchal society, and also leads to the conclusion that women's lives are full of loneliness.

Even though Dickinson were not married all her lifetime, her legendary love experience and her relentless pursuit of love still gave her great strength for the formation of her views on love. As a poet, she was willing to be lonely. But as a woman, she could not bear the loneliness of love.

Actually, Emily had hazy romantic feelings with several gentlemen. Richard Swell, one of the most authoritative Dickinson biographers, recorded two of the most important loves in her lifetime: one was the love with Samuel Bowles, with no result at last; the other was the love with Rhodes, who was a judge 18 years older than Dickinson.

In her lifetime, more than once had she encountered her idol. One of her idol was a young lawyer named Benjamin Franklin Newton (1821-1853). The lawyer was talented and had taught Dickinson how to read books and write poetry. Dickinson fell in love with him very soon. In Newton's influence, Dickinson started writing poetry around 1850. The lawyer had a profound impact on Dickinson's view of the world. Newton's untimely death in 1853 made Dickinson very extremely grieved. To young Emily, this was quite a severe blow.

In 1854, Dickinson met Pastor Charles Wordsworth on a trip. She fell in love with the pastor and 
regarded him the dearest friend. Wordsworth made Dickinson to be a poet (Johnson, 1995: 80). She wholeheartedly loved this Wordsworth, whom she knew she can not partner with. This gave her the opportunity to experience the subtle emotional up and down stages of the heterosexuality, and to conjecture and speculate on each side of love. She even created a "lover" based on Wordsworth in her poem to rest her feelings. In 1862, Wordsworth moved to a new deanery in San Francisco, California. To Dickinson, this was a great mental blow again, which almost put her into desperation. Since then, she decided not to see anybody and started to write poetry all day long to express the pain of her lost love and her aspiration of pure love. This year alone, she wrote more than 300 poems full of blood and tears.

Dickinson met her third friend of the opposite sex is a talented, passionate newspaper editor named Samuel Bowles. The two kept in touch up to 20 years, and they expressed their saccharine love during their communication. The only poems Dickinson published during her lifetime were mainly on the Springfield Republican Daily edited by Bowles (Shoulan Liu, 2006: 331).

Dickinson also met another newspaper editor Thomas Higginson. She wrote a letter to him, attached with four poems, asking for his evaluation and recommendations. Even though Higginson suggested not directly express her poetry, he still noticed the new originality in her poetry. After that, he became Dickinson's mentor.

Dickinson dedicated her passionate love in the twilight years of life to the Massachusetts senior judge Otis Rhodes. After the death of her parents, Dickinson rested her feelings on old friend Rhodes. The two wrote to each other letters frequently, and they had an intimate relationship. They were not married, but they loved each other sincerely. In 1884, the beloved Rhodes died, caused great trauma in Dickinson's heart. Two years later, Dickinson left the world with pain and grudge, to follow those who loved her and gave her the opportunity to experience true love.

Feminine influences Emily Dickinson's view of love

A series of setbacks Dickinson had experienced in her love caused serious damage to her heart, and she endured great pain and suffering. As a poet with existentialism and feminist tendencies, in the strong sense of self consciousness, she divinely and rational examined the love between the two sexes. She thought that love is the initiative nature between men and women, who are supposed to have equal rights to love and to be loved.

Dickinson is so elusive as to escape manipulation of traditional marriage and pursue independent and equally love. In the famous poem "Wild Nights", Dickinson is aware of female self consciousness. She expressed her love bravely and openly:

Wild nights! Wild nights!

Were I with thee,

Wild nights should be

Our luxury!

(Dickinson, 1976: 249)

Having experienced two hopeless loves, she chose to be celibate, abstain from marriage and childbearing. She was unwilling to lose equal status she should have, unwilling to dependent on men. She just wanted to be loyal to herself. Her "I'm 'wife' — I've finished that — " (Dickinson, 1976: 199) is a masterpiece of a performance of female awakening awareness of family status. The sentence "I'm 'wife'! Stop there!" pushed the poet's irony and doubt toward the positioning of the role and value of women that society and customs had made to a climax. This means that women should be clearly aware of their status in marriage, attached to her husband and marriage is not the only safe and happy lifestyle. She set an example from the very beginning by staying away from the fetters of marriage, staying out of the cage of patriarchy wife and mother. On that condition, she was full of creative vitality, full of the desire for self-expression.

\section{Conclusion}

Emily Dickinson, a figure familiar in Amherst a hundred years ago, is still not so easy to know today. Emily Dickinson's poetic genius is appreciated by many people throughout western literary history. Since then, in the following years, Emily Dickinson's high status in literary field is no longer 
doubted.

Emily Dickinson explores much more for women's rights and privileges, the most important thing is that she arouses female self-consciousness and uses a kind of men's brain to express her feminine awareness, so Dickinson creates a new age for women in American literature field. Dickinson is a symbol of feminism because she stands up for her woman beliefs. Modem feminists admire her, for she anticipates a pattern now considering liberating: refusal to make choices between sexuality and intellect, security and independence, marriage and career. She breaks out of the circle of limitations made by patriarchal society. She shows her audience how she feels about the world's outlook on woman and demonstrates that as an aggressive, self-confident woman can do everything.

Emily Dickinson's feminine awareness awakening develops gradually not a sharp breakthrough. Because of Dickinson's normal education in feminist school, she has the ability to think about the patriarchal world, she clearly acknowledges the unequal between men and women, and she recognizes that the patriarchal society is the unbalanced and lack if it lacks the women's voices. So Dickinson's feminine awareness awakens, she chooses to be a poet in order to express her unique femininity, from her femininity poetry, we hear a voice not just "woman" but a voice uniquely all women.

What the author tries to do in this thesis is to prove Emily Dickinson's feminine consciousness awakening in her femininity poetry by describe Emily Dickinson's life and thoughts. She chooses to dedicate her life to write femininity poetry and struggles for the integrity of female's own voices, and wants to be the Queen of the poetic realm, indeed, she makes it.

\section{References}

[1] Emily Dickinson. The Compete Poems of Emily Dickinson[M]. New York: Back Bay Books, 1976.

[2] Elizabeth A. Petrinao. Emily Dickinson and Her Contemporaries[M]. London: UP of New England, 1998.

[3] Jack L. Capps. Emily Dickinson's Reading[M]. Austin: University of Texas Press, 1996.

[4] Jean Could. American women poets: Pioneer of Modern Poetry[M]. New York: Dodd, Mead \& Company, 1980.

[5] Paula Bernat Bennett. Poets in the Public Sphere: The Emancipatory Project of American Women's Poetry[N]. Princeton: Princeton UP, 2003.

[6] R. Franklin. The Poems of Emily Dickinson: Variorum Edition[C]. London: The Belknap Press of Harvard University Press, 1998.

[7] Thomas H. Johnson. "Emily Dickinson", An Interpretive Biography[M]. Cambridge: The Belnap P of Harvard UP, 1995.

[8] Thomas H. Johnson. The Poems of Emily Dickinson[C]. Cambridge: Harvard University Press, 1955.

[9] Thomas H. Johnson, Theodora Ward. The Letters of Emily Dickinson[M]. Cambridge: Harvard University Press, 1958.

[10]Wendy Martin. Emily Dickinson[M]. Shanghai: Shanghai Foreign Language Education Press, 2004. 